\title{
Critical Review : Significant Impact of ICT in Higher Education Examination System
}

\author{
Pravin Pandit Shinkar ${ }^{1}$, Dr. Bechoo Lal ${ }^{2}$ \\ ${ }^{1}$ Research Scholar, Dept. of Computer Science, SJJT University, Jhunjhunu, Rajasthani, India \\ ${ }^{2}$ Assistant Professor, Dept. of Information Technology, Western College, University of Mumbai, India
}

\begin{abstract}
In this research article the researcher discussed the critical review and significant impact of ICT in higher education examination system. The researcher emphasized that some of the significant research issues on ICT which is having lot of possibilities in improving the whole examination system. Trend of seeking online applications for regular, examinations and conducting on-line examinations have made the system very simple and cost effective for the examining bodies. This paper presents the growing role of examinations in improving the quality of education by embracing the integrated automated exam system for providing the robust, transparent, accurate and authenticated outputs. This automated exam system through ICT will bring substantial quality improvement in education. A part from implementing ICT quality, problem in exam has also been discussed. ICT will make exam system more efficient and transparent account.
\end{abstract}

Keywords : ICT, Examination System, Open Educational Resources

\section{INTRODUCTION}

Information and communication technology is playing crucial role in the higher education. ICT has become an integral part of everyday life for many people. It is expected that the trend will continue in increasing the importance of ICT in people's lives and, to the extent that ICT literacy will become a functional requirement for personal lives, work and social life. These are directly influencing the way human beings are engaging themselves in their routine activities. The socio-economic environment needs a catalyst to bring social change in the human development. Large scale deployment of communications technologies has produced major changes in the way we communicate for social and business purposes and most of these deployments are technology-led. The internet, television, mobile phones, computer-based devices and other new forms of information technology are changing rapidly and are also influencing the social life. ICT applications can support sustainable development, in the fields of public administration, business, education and training, health, employment, environment, agriculture and science.

The development and use of technology has greatly improved our lives. It is dependent on technologies to accomplish specific tasks in our lives. With the use of various emerging technology life has become very comfortable. Technology is being implemented in almost every segment of our lives and businesses. ICT covers all the technological tools to process and communicate information. It includes two aspects of information technology and communication technology. Information technology encompasses all matters relating to the acquisition, manipulation, and management of information. Communication 
technology encompasses all the matters to the transfer and sharing of information.

Examinations play an important role in imparting education and knowledge to students. Examination is an instrument to evaluate the knowledge, understanding and learning of studens.For teachers, Examinations provides feedback their way of teaching. In the last couple of decades, higher education has witnessed tremendous growth in terms of number of students enrolled, number of courses offered, and number of affiliated colleges etc. As a result of this growth, the examination system at universities quite complex and complicated.

In Maharashtra, serious concerns have been expressed on various allegations regarding leakage of university examination papers and negative image being portrayed by the media about the capabilities of Universities to hold \& organize examinations in a fair manner. ICT is playing crucial role to resolve issue. On line paper delivery system sends the question paper 45 minutes prior to examinations. This is reliable system and university can conduct examination smoothly .There is scope to improve the system from online to real time mode.

\section{BACKGROUND OF RESEARCH STUDY}

[1]. J. Enrique Hinostroza, Christian Labbé \& Magdalena Claro (Oct. 2005) Regarding the location of computers, the fact that the majority of the computers in primary and secondary schools are located in the computer labs is mainly due to the ICT in Education policy in Chile. This program provided computer labs to schools without the possibility of installing these computers in the classrooms. Therefore, the fact that some secondary schools do have a few computers in the classrooms is due to their own initiative. These results support the assumption that the majority of students' and teachers' ICTrelated activities are carried out in the computer lab. Additionally, the relatively high percentage of schools connected to Internet enables ICTrelated activities and use of Internet resources.

[2]. Khalid Abdullah Bingimlas((2009) The aim of this paper was to provide information on encouraging the desired improvement in the future teaching situation to those responsible for the integration of ICT into science education. The findings of this study indicate that teachers have a strong desire for the integration of ICT into education but that they encountered many barriers to it. The major barriers were lack of confidence, Lack of competence and lack of access to resources

[3]. Steve U. Basse, Diepreye Okodoko\&Uduak D. Akpanumoh(April 2009) it was an attempt to explain the crucial role that ICT can play in the effective management of higher education for sustainable development in the developing countries of Africa in the 21st century. Specifically, the paper analysed the variables ICTs in university teaching, learning, research, administration and challenges of massive application of ICTs in African universities.

[4]. M Wasif Nisar, Ehsan Ullah munir and shafqat Ali shad (2011) The major finding of this paper is that availability and usage of ICT is very essential to improve the educational efficiency of students' and. After analysing all the results we conclude that ICT brings a positive impact on education sector of Pakistan

[5]. Zafar Ahmed SHAIKH \& Shakeel Ahmed KHOJA (January 2011) This study adds rigor in ICT policy and planning, administration, and integration at the higher education level and affirms that an effective and robust ICT policy for HES can change the current status of Pakistan as poor in terms of a knowledge-based economy to rich. The recommendations and 
empirical evidence collected from this study are important contributions to the literature.

[6]. Charles Musarurwa (2011) the major challenges facing the integration of ICT into the teacher education curriculum in Zimbabwe are sustainability and replication. Firstly, it was an external partner who managed to identify the gap that existed within the higher education sector, particularly within teacher education, that there was a need to provide both ICT resources and skills. Yet, teacher education colleges should have been treated as the nerve centre of the whole computerization programmer.

[7]. Secondly, although the CITEP programme remains one of the most tangible and successful programme yet in the history of teacher education in Zimbabwe, it still remains too little and too late. It can be described as a trial or pilot programmed, since it operated in three secondary teacher education colleges only. The other 12 colleges were not involved and will need to undergo the same development. Taking into account that it was an external partner who identified the knowledge and resource gap and funded the programme, then it may be an uphill task for the other colleges to develop to the same level, since the external partner is now involved in other programmes. If both the Ministry of Higher and Tertiary Education and the remaining colleges work hand

[8]. Ajit Mondal \& Dr. Jayanta Mete (2012) The four most common mistakes in introducing ICTs into teaching are I) installing learning technology without reviewing student needs and content availability; ii) imposing technological systems from the top down without involving faculty and students; iii) using inappropriate content from other regions of the world without customizing it appropriately; and iv) producing low quality content that has poor instructional design and is not adapted to the technology.

[9]. Sukanta Sarkar(May 2012) As move into the 21st century, many factors are bringing strong forces to bear on the adoption of ICTs in education and contemporary trends suggest will soon see large scale changes in the way education is planned and delivered as a consequence of the opportunities and affordances of ICT. It is believed that the use of ICT in education can increase access to learning opportunities. It can help to enhance the quality of education with advanced teaching methods, improve learning outcomes and enable reform or better management of education systems. Extrapolating current activities and practices, the continued use and development of ICTs within education will have a strong impact on: What is learned, how it is learned, when and where learning takes place, \& who is learning and who is teaching. The continued and increased use of ICTs in education in years to come, will serve to increase the temporal and geographical opportunities that are currently experienced. The integration of ICTs in higher education is inevitable. The very high demand for higher education has stimulated significant growth in both private and public provision. ICTs in the form of Management Information Systems are increasingly universal. The strength of computers in teaching is their power to manipulate words and symbols - which is at the heart of the academic endeavour. ICT has also led to the emergence of Open Educational Resources (OERs).

[10]. Sharmila Devi, Mohammad Rizwaan\&Subhash Chander (June 2012) Paper deals with Quality education through ICT and its awareness among stakeholders will have positive impact on the society. ICT can be helpful in quality and standards of education by implementing it in various phases of education. ICT can be 
employed in formal and Non-formal types of education and would eventually make the learners employable and socially useful part of the society. By employing ICT in teacher training can save a lot of money of the Government. Moreover a lot of qualitative improvement can be seen as resource persons for the training can be best of the world. By employing ICT in administration can help in solving the problem of Absenteeism of students and teachers. Good quality content is one of the major issue and directly affects the standards of education and quality. By overcoming the certain challenges involved in the process of education can help a lot in this side. Conclusively a lot of quality improvement is possible after careful and planned implementation of ICT in education by various stakeholders.

[11]. Alexander Aristovnik (July 2012)The empirical results also suggest that, in general, some less developed EU countries such as Slovakia and Poland show a relatively high level of ICT efficiency due to the low level of their ICT inputs. Therefore, a significant increase in ICT expenditures is needed in those countries. All in all, the analysis finds evidence that most of the countries under consideration hold great potential for increased efficiency in ICT and for improving their educational outputs and outcomes.

[12]. Paul P.K. and Mondal N.K November (2012) Paper deals with following objectives and conclusion: - Study: I. to find out the impact of ICTs in school education. Into compare the views of teacher's educator regarding effect of ICT in improving quality of education. iii. To examine any disparity exists among male or female students about the applicability of ICT in school. iv. To suggest the best possible outcome regarding effectiveness of ICT in school education.

[13]. Meenakshi (2013) Paper describes ICT adds value in learning process and management of learning institutions. Many countries now regard understanding ICT and basic skills and concept of ICT as part of the core of education. Paper also describes reluctant due to poor software design and lack of administrative support.

\section{PROBLEM STATEMENT AND RESEARCH OBJECTIVES}

ICT is playing important role in higher education. Impact of ICT is not only limited to Teaching \& Learning methods but also various services to students in higher education. Whatever services students are getting are not getting on time. Currently University of Mumbai is working on online and offline mode. The university examination system is changing at a dramatic rate. There are multiple processes going on within the examination system Improving the efficiency of examination systems is one of the most challenging goals of today's society. There is need of research work in higher education to overcome all issues and deliver quality services to all stakeholders of university.

1. To identify the existing disadvantages and deficiencies.

2. To study the different examination pattern

3. To study examination system constraints and its significant impact

\section{FRAMEWORK OF THE RESEARCH STUDY}

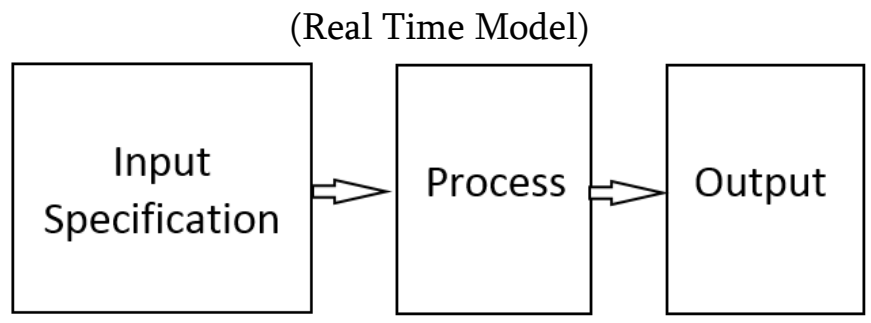

Fig.1.1: Proposed High Level Model 


\section{A. Input Specification}

Methodology adapted for Data collection is main process of preparing and collecting data, from the organization. The purpose of data collection means select the data from the total population which has been decided by the research area.

Random sampling method will be adapted to select the sample size from the total data. This is also called primary data. Secondary data shall be collected from the research paper, ordinances, circulars and government resolutions from the organization.

\section{Data Analysis and Verification of Data:}

\section{Attributes}

i. student name

ii. college

iii. subjects

iv. Fresh/Repeater

v. Eligibility

vi. Language of Answer

vii. Economically Backward

viii. Improvement

Examination plays a significant role in a university education system. Examination is an important tool to test the student cognitive skill and retention during course of study. University examinations have motivating effect on both students and teachers. It motivates the student to put in best efforts to attain his goals, Examination may be used as a tool to organize and integrate knowledge. It encourages student toward study and read various books and integrate ideas to respond to a given problem in a problem based learning system. For a teacher too, examination gives a stimulus and goal orientation to his work, not. It may say that the examinations become inevitable as students and teachers work will neither have precision nor any direction without it
There is need to automate the existing examination system, because the manual examination system was used when the numbers of students registered were less and the numbers of courses taught were less. In present scenario the increasing burden of examination due to increase in GER is leading to inefficiencies. We can minimize human intervention by adopting ICT since the technology leads to compact storage, speedy retrieval of data

The researcher focused on the challenges of main feature of ICT i.e. integration of ICT in examination system in following way-

1. Lot of investment is needed on the part of universities and school examination boards as technology is quite costly.

2. Lack of ICT trained people is another challenge, for which proper training programmes in a regular manner are to be organised.

3. Less initiative taken by the state universities to integrate ICT in the examination system due to lack of funds.

4. Maximum student population of the country is living in the rural areas and not has access to the new technologies.

5. Changing the mind-set of the people presently using manual system and making them trained.

Indian educational system gives lot of importance to the examinations. At every step of our educational process we depend upon the examinations. Examination is the pivotal point around which the whole system of education revolves and the success or failure on the parameter of examination is indeed an indicator of the success or failure of that particular system of education. Examination may be used as a means to organize and integrate knowledge, it encourages student to go through various books and integrate ideas to respond to a given problem. 


\begin{tabular}{|c|c|}
\hline \multicolumn{2}{|c|}{ University Examination System } \\
\hline Flow Chart & Algorithm \\
\hline
\end{tabular}

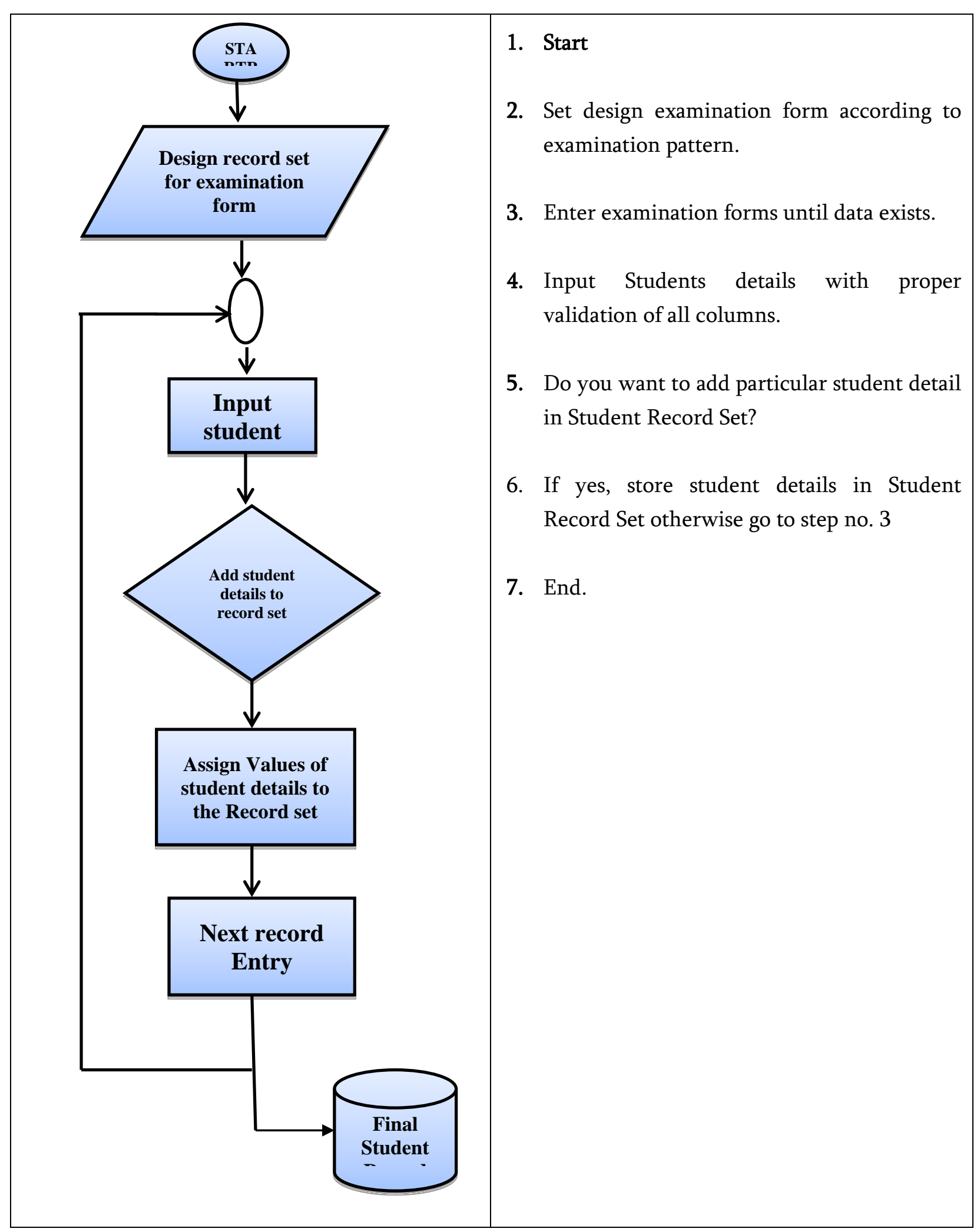




\section{B. PROCESSES SPECIFICATION}

Following are the different process in examination system

1. College-wise Count

2. Edit List

3. Paper Code Generation

4. Seat Number Generation

5. College-wise List

6. Centre-wise List

7. centre-wise Statistics

8. Admit Cards

9. Mss. Report

10. Subject-wise count

11. Time Table Entry

12. Daily Pasting Subject-wise

13. Daily Pasting Venue-wise

14. Venue Allocation

15. Internal Mark-list

16. Internal Marks Entry

17. Internal Marks Posting

18. Internal Marks Discrepancy

19. Theory Marks Posting

20. Theory Marks Discrepancy

21. Examiner Grace Statistics

22. Examiner Grace Implementation

23. Internal Marks Adjustment

24. OR Calculation

25. OR Printing

26. Mark-sheet and Passing Summary Report

27. Mark-sheet Printing

28. Passing Printing

29. Merit List Aggregate

30. Merit List Subject-wise

\section{TOOLS AND TECHNIQUES USED FOR REAL TIME EXAMINATION.}

1. Round Robin Method for Answer-book assessment.

2. Triggers for controlling various events examples:- a. Completion of Data

b. Eligibility

c. Lower exam clearance

d. Data storage and retrieval

e. Performance evaluation by system

f. Technology used

i. Linux, PHP

ii MySQL

iii Hardware Specification

32 core Intel Xeon CPU, HDD- 6TB, 32

GB RAM

iv. Network configuration - 50 mbps

\section{Web Camera}

C. REAL TIME EXAMINATION SYSTEM (OUTPUT):

1. Student will get seat number and venue detail through admit card.

2. Details of answer- books to Department.

3. Scanning of Answer-book.

4. Ready for Assessment.

5. Assessment message forwarded to concern department.

6. Paper-wise Analysis of assessment related to student.

7. Grace marks and Result calculation implementation.

8. Student can get result in real time mode.

9. College will get gazette in real time mode.

10. Real time information to marks and certificates.

11. Action taken by concern department on the basis of information.

12. Acton taken by concern department on the basis of information.

\section{VII.CRITICAL REVIEW ON ICT BASED EXAMINATION SYSTEM}

The researcher is trying to trouble shoot the challenges in examination system with ICT, hence quote that, "India is not a rich country where we can change the whole picture in one day. Being a 
developing nation, the country is facing lot of problems in every sphere. ICT based examination system is quite costly in the initial stage and in case country manage to invest for changing the manual system to ICT we will be facing the challenges on the part of learner who have to adopt the same. Maximum universities, educational boards and selection bodies are inviting the examination applications online. Students who are rural and not have the access to the new technology have to visit cities for filling the application forms. In that case they depend on the people who are managing the cybercafés. Maximum time it has been observed that their forms get rejected due to filling wrong information by such people. Providing proper orientation to the students regarding using the technology is one of the main challenges."

In two years of span the speedy development of ICT implementation in examination is quoted by Dr. Anurag Sankhiyan, that, "Trend of seeking online applications for regular, entrance /competitive examinations and conducting on-line examinations have made the system very simple and cost effective for the examining bodies. But, on the other hand, this change is also bringing lot of challenges to the rural youth of the country who are not that much techsavvy. The present paper, focus on the possibilities and challenges of integrating ICT in examination system."

Ron Oliver in his research paper titled "The role of ICT in higher education for the 21st century: ICT as a change agent for education" stated that, the world moving rapidly into digital media and information, the role of ICT in education is becoming more and more important and this importance will continue to grow and develop in the 21st century. The paper argues the role of ICT in transforming teaching and learning and seeks to explore how this will impact on the way programs will be offered and delivered in the universities and colleges of the future.

\section{CONCLUSION}

In this research paper the researcher concluded that Examination are integrated part of our educational system. With the technological revolution, the electric media is replaced by the digital media or ICT and virtually every aspect of human behaviour or activity is in some way or another dependent on the new computer technologies. It is a fact that, ICT has great potential for knowledge dissemination, effective learning and the development of more efficient education services. ICT has opened new avenues in education by way of increased accessibility of resources and better interaction processes. In the case of Examination system, all the universities and school education boards are under a process of change from manual to computer technologies / ICT. This change in the examination system will minimize human intervention by adopting ICT since the technology promises compact storage, speedy retrieval of data and untiring diligent work. Global reforms in education and challenging ICT demands have also made a remarkable shift in the structure of ICT environment and the utilization of ICT in education. ICT is having lot of possibilities in improving the whole examination system.

\section{REFERENCES}

[1]. J. Enrique Hinostroza, Christian Labbé \& Magdalena Claro, and ICT in Chilean school: Students and teachers access to and use of ICT, ISSN: 1795-6889, Volume 1 (2), 246-264, October 2005.

[2]. Khalid Abdullah Bingimlas((2009), Barrier to the successful integration of ICT in Teaching and Learning environments, ISSN 1305-8223, 5(3),235-245, Year 2009. 
[3]. Steve U. Basse, Diepreye Okodoko\&Uduak D. Akpanumoh (April 2009), Information Communication Technologies in the Management of Education for Sustainable Development in Africa, ISSN 1994-9057 (Print) ISSN 2070-0083 (Online) Vol. 3 (3), April, 2009.

[4]. M Wasif Nisar, Ehsan Ullah munir and shafqat Ali shad, Usage and impact of ICT in Education sector: A Study of Pakistanis' 1991-8178 Volume 5(12), 578-583, 2011.

[5]. Zafar Ahmed SHAIKH \& Shakeel Ahmed KHOJA, Role of ICT in shaping the future of Pakistani higher education system, TOJET: The Turkish Online Journal of Educational Technology volume 10 Issue 1, January 2011.

[6]. Charles Musarurwa, Teaching With and Learning through ICTs in Zimbabwe's Teacher Education Colleges, ISSN 1548-6613, A 7 952-959,2011.

[7]. Ajit Mondal \& Dr. Jayanta Mete, ICT in Higher Education: Opportunities and Challenges, (ISSN 2249-3301), Vol. II, 2012.

[8]. Sukanta Sarkar, The Role of Information and Communication Technology (ICT) in Higher Education for the 21st Century, ISSN 2277 9566, Vol. 1 No. 1 Page No- 30-40, (May 2012).

[9]. Sharmila Devi, Mohammad Rizwaan\&Subhash Chander, ICT for Quality of Education in India, ISSN: 2249-5894 Volume 2, Issue 6 June 2012.

[10]. Alexander Aristovnik, The impact of ICT on educational performance and its efficiency in EU and OECD countries: a Non Parametric analysis, volume 11 Issue 3, July 2012.

[11]. Paul P.K. and Mondal N.K.,Integration of ICT in School Education: An Analytical Study in Burdwan District in West Bengal, India, ISSN 2319-1171, Vol. 1(4), 21-25, November (2012).

[12]. Meenakshi, Importance of ICT education, ISSN: 2320-7388, p-ISSN 2320-737X Volume I Issue 4 (May-Jun 2013) PP 03-08.

[13]. Nana Yaw Sabered, Hamelin Mohammed Ahmed, Towards Enhancing Quality in Education through Information and Communication Technologies (ICTs) in Higher Educational Institutions (HEIs),
International Journal of Computer Applications (0975 - 8887) Volume 62- No.8, January 2013.

[14]. Jo Shan $\mathrm{Fu}$, a Critical Literature Review and Its Implication, (IJEDICT), Vol. 9, Issue 1, pp. 112125, 2013.

[15]. Vimbai Edina Ndawi, Kennedy Andrew Thomas\& Tendayi Leonorah yaruwata, Barriers to Effective Integration of Information and Communication Technology in Harare Secondary Schools, ISSN: 2319-7064 Volume 2 Issue 9, September 2013.

[16]. Munienge Mbodila, Telisa Jones, Kikunga Muhandji (Nov. 2013). Integration of ICT in Education: Key Challenges ISSN 2250-2459, Volume 3, Issue 11, November 2013).

[17]. Uttam $\mathrm{Kr}$ Pegu (2014). Information and Communication Technology in Higher Education in India: Challenges and Opportunities, Volume 4, Number 5 (2014), pp. 513-518.

[18]. Jota Narayan Patra((June 2014), The Role of ICT in improving the Quality of School Education in India, ISSN 2277-2456, Volume-III, Issue-II, AprMay-June 2014.

[19]. Rajeev Puri, Cloud Computing in Education and Sports in India, ISSN: 2229-6913, Issue, Vol. 10, and June 2014.

[20]. Brijendra Singh Yadav \& Ajay Poddar, ICT At University level management education -one step forward in shaping right human resource of tomorrows india, ISSN: 2348-3083. VOL. I/IV, June-July 2014.

\section{Cite this article as :}

Pravin Pandit Shinkar, Dr. Bechoo Lal, "Critical Review : Significant Impact of ICT in Higher Education Examination System", International Journal of Scientific Research in Science and Technology (IJSRST), Online ISSN : 2395-602X, Print ISSN : 2395-6011, Volume 6 Issue 6, pp. 202-210, November-December 2019. Available at doi : https://doi.org/10.32628/IJSRST196639 Journal URL : http://ijsrst.com/IJSRST196639 